Volume 12 Number 3, July-September 2018: pp. 192 - 205. Copyright (c) 2018 FIAT JUSTISIA. Faculty of Law, Lampung University, Bandarlampung, Lampung, Indonesia. ISSN: 1978-5186 | e-ISSN: 2477-6238.

Open Access: http://jurnal.fh.unila.ac.id/index.php/fiat

Fiat Justisia is licensed under a Creative Commons Attribution 4.0 International License, which permits unrestricted use, distribution, and reproduction in any medium, provided the original work is properly cited.

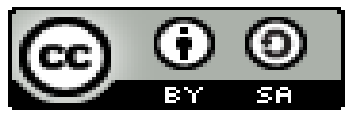

\title{
Comparison of the President Prerogative Rights in Indonesia Constitutions
}

\author{
Oksep Adhayanto \\ University of Raja Ali Haji Maritime, Indonesia \\ adhayantooksep@umrah.ac.id \\ Irman \\ University of Raja Ali Haji Maritime, Indonesia \\ irman@umrah.ac.id \\ Fithriatus Shalihah \\ University of Riau Islamic, Indonesia \\ fithriatus@law.uir.ac.id
}

\begin{abstract}
Prerogative rights can be interpreted as privileges or privileges, The Indonesian constitutional history that has used several constitutions indirectly has implications for the practice of the use of prerogative rights in Indonesia. This study research on the preogrative rights of the President in the Constitutions of Indonesia. The approach used in this study is normative juridical with the law approach model. It is concluded that the use of prerogative rights has ups and downs influenced by the concept of checks and balances and distribution of power. Therefore, the use of prerogative rights as in the previous constitution is more directed to heavy executives who do not require confirmation to other state institutions, now it has begun to be restricted so the use of the term prerogative privileges is no longer pure as before.
\end{abstract}

Keyword: President, Prerogative Rights, Indonesia Constitution 
How to cite: Oksep Adhayanto, Irman, and Fithriatus Shalihah "Comparison of the President Prerogative Rights in Indonesia Constitutions", Fiat Justisia, 12 (3), (2018).

DOI: https://doi.org/10.25041/fiatjustisia.v12no3.1329

\section{A. Introduction}

Prerogative linguistically comes from Latin Language praerogativa (selected as the first to vote), praerogrativus (asks as the first to vote), praerogare (asks before asking another) ${ }^{1}$. In another sense, there are also those who define prerogative as a privilege. Meanwhile, prerogative rights according to the Big Indonesian Dictionary are defined as privileges that exist in someone because of his position as head of state. ${ }^{2}$

Before the amendment to the 1945 Constitution, the sign of the president's prerogative can be seen in Article 11.12, 13, Article 14, Article 15, and Article 17. Through these articles, the president has the freedom to run the government without intervention from other institutions, for example, the House of Representatives (DPR). It is as if the application of the provisions in these articles is absolutely the power of the president. ${ }^{3}$

Several opinions also stated that prerogative right is equal to constitutional privilege by means that those rights had clear regulation in the nation's constitution. That constitutional right is the privilege given to the president hence regulated in the nation's constitution. Scientifically, the view on prerogative right mostly contains opinions from state administrations experts that exist. That thinking evokes pro and contradictive manners in giving an interpretation of prerogative right usage. The state administrative law graduates that convey their opinions on prerogative right amongst them is Mahfud MD who stated:

"Whether or not a prerogative right exists in a constitution, it will not be an issue, depending on how that prerogative right is interpreted. For the prerogative right exists if the President has the right to do a certain act without asking for permission from another individual or other institutions. As a result, the prerogative right does not have to be necessarily annulled, but lessened". ${ }^{4}$

By prerogative right, S. Toto Pandoyo stated that :

\footnotetext{
${ }^{1}$ Bagir Manan, "UUD 1945 Tak Mengenal Hak Prerogatif”, (Republika, Sabtu, 27 Mei 2000), p. 8.

${ }^{2}$ Tim Prima Pena, Kamus Besar Bahasa Indonesia, Gita Media Press, (tt), p. 274.

${ }^{3}$ Riri Nazriah, "Pemberhentian Jaksa Agung dan Hak Prerogatif Presiden", Jurnal Konstitusi, 7, (5), (2010), p. 22.

${ }^{4}$ Ni'Matul Huda, Politik Ketatanegaraan Indonesia; Kajian Terhadap Dinamika Perubahan UUD 1945, Yogyakarta: FH. UII Press, (2003), p. 121.
} 
"Ahead of state, may it be a king or a president, surely owns prerogative right or some may say with a special term or special rights. For democratic law countries, provision and kinds also amounts of referred prerogative rights are stated firmly in the relevant nation's constitution". ${ }^{5}$ Hendarmin Ranadireksa, express his opinion regarding prerogative rights as followed:

"In his function as a person who can do no wrong, ahead of state has exclusive rights or special rights that no other function of state offices possesses, that is prerogative rights. Prerogative right is the head of state's right to issue a decision on behalf of the country, being final, binding, and having a fixed law power. Prerogative right is the highest right available and provided by the constitution for the head of state and is regulated in the nation's provision that is specially designated to that material (UUD)". ${ }^{6}$

Blackstone defines prerogative rights as followed:

"... that special pre-eminence which the King hath over and above all other persons, and out of the ordinary course of the common law, in right of his regal dignity. It signifies, in its etymology (from prae and rogo) something that is required or demanded before, or in preference to, all others. "7

Based on the problem that has been said above, the writer is interested in the use of prerogative rights for some Constitution in Indonesia with a title Comparison of the President Prerogative Rights in Indonesia Constitution. The question of this research is how the Comparison of the President Prerogative Rights in Indonesia Constitution?

\section{B. Research Methods}

This study uses Juridicial Normative ${ }^{8}$ with law approach model. And using secondary data in the form of Primary Law, Secondary Law, and Tertairy Law. The nature of this research is descriptive analytic while the data were analyzed using qualitative analysis methods.

\section{Discussion}

\section{President Prerogative Rights on Law 1945 Years 1945 until 1959}

\footnotetext{
${ }^{5}$ Ibid, p. 117.

${ }^{6}$ Hendarmin Ranadireksa, Visi Bernegara : Arsitektur Konstitusi Demokratik, Mengapa Ada Negara yang Gagal Melaksanakan Demokrasi, Bandung: Fokusmedia, (2007), pp. 198-199.

7 Hilaire Barnet, Constitutional \& Administrative Law, United Kingdom: Cavendish Publishing Limited, The Glass House, (2002), p. 135.

${ }^{8}$ Soerjono Soekanto dan Sri, Penelitian Hukum Normatif Suatu Tinjauan Singkat, Jakarta: Raja Grafindo Persada, (2001), p. 13-14.
} 
Constitution law manuscript before the amendment was prepared before the war. Japan soldiers still were occupied Indonesia. In Constitution Law 1945 system as Supomo stated, indeed it was designed in a certain way that the power was centered for the Presidents (concentration of power and responsibility upon the presidents) or based on the popular phrase "executive heavy." Even on Dokuritzu Zyumbi Chosa Kai Meeting, Supomo said :

"... for the President's (daily administration) administration which is the incarnation of people's sovereignty". "... which is the incarnation of the people's sovereignty is the President, not the people's council".

So as an affirmation that stated on Article 4 paragraph 1 Constitutional Law 1945, said President of Republic Indonesia Likewise, the affirmation in Article 4 Paragraph (1) UUD 1945, declare Presiden Republik Indonesia holds the power of government according to the constitution. So the executive function is handed over to the President.

At the beginning of the administration of the government based on the 1945 Constitution before the amendment was adopted by the Presidential system where the President held power as Head of Government and also as head of State, this could be seen from the provisions of article 4 paragraph (1) of the 1945 Constitution before the amendment that the President of the Republic Indonesia holds the power of government and according to the provisions of article 17 paragraph (1), (2) and paragraph (3) of the 1945 Constitution before the amendment determines that the President is assisted by state ministers. The Ministers are appointed and dismissed by the President; the ministers lead government departments. ${ }^{9}$ From the provisions of Article 4 and Article 17 of the 1945 Constitution before this amendment, it is clear that the system of government adopted is a presidential system, namely the President holds the power of government, ministers are appointed and dismissed by the President. These ministers are not responsible to the House of Representatives but depend on the President. They are assistants to the President (Number IV Explanation of the 1945 Constitution). This provision is a characteristic of a presidential system in the administration of the state. Some of the sovereignty by the 1945 Constitution before the amendment was submitted to the President of the Republic of Indonesia, among others, was the function of the Head of Government and the function of the Head of State. The President as Head of Government, has the power, among others, the President holds the power of government. What is meant by the government is all matters in organizing

\footnotetext{
${ }^{9}$ Mohd. Kusnardi dan Harmaily Ibrahim, Pengantar Hukum Tata Negara, Jakarta: Pusat Studi Hukum Tata Negara Fakultas Hukum Universitas Indonesia, (1983), pp. 171-180.
} 
the welfare of the people and the interests of their own country (Article 4 paragraph (1) of the 1945 Constitution).

On the other hand, the President is not responsible to the House of Representatives, meaning that the President's position is not dependent on the House of Representatives. This is because at that time state institutions had not been established. As a result, all powers were delegated to the President through Article IV of the Transitional Rules which read;

" Before the People's Consultative Assembly, the People's Legislative Assembly, and the Supreme Advisory Council were formed according to the Constitution; all its powers were carried out by the President with the help of a National Committee."

About the Relationship between institution Wilopo said there are balances or check and balances regarding the relationship between these institutions, Wilopo mentioned a balance or check and balances typically between the government and the House of Representatives which are equally strong. The House of Representatives is strong because the government can not dissolve it, and the government also because the House of Representatives can not impose it. ${ }^{10}$ Some of the power considered as Presidents Prerogative Rights on that era is to hold the power that makes Constitution with House of the Representative agreement. ${ }^{11}$ President set Government Regulations to enforce the law; The President appoints ambassadors and consuls, ${ }^{12}$ the President gives clemency, amnesty, abolition, and rehabilitation. ${ }^{13}$ The President gave matrimony, honors, and other honors. ${ }^{14}$ The President has the authority to appoint and dismiss state Ministers. ${ }^{15}$

The concentration of power that lies in the hands of the president ${ }^{16}$ based on Article IV of the Transitional Rules turns out to cause problems relating to public opinion, AG. Pringgodigdo stated, among people who were not happy with the establishment of the Republic of Indonesia, an opinion was developed that the country of Indonesia was not a democratic country, but a fascist or Nazi state led by a Fuhrer or Duce, ${ }^{17}$ According to Mahfud MD, in fact, if seen in paragraph 1 of the Additional Rules of the 1945

10 Wilopo, Zaman Pemerintahan Partai-Partai dan Kelemahan-Kelemahannya, Jakarta: Yayasan Idayu, (1976), p. 66.

${ }^{11}$ Article 5 Paragragh 1 Constitutional Law 1945

${ }^{12}$ Article 13 paragraph 1 Constitutional Law 1945

${ }^{13}$ Article 14 Constitutional Law 1945

14 Article 15 Constitutional Law 1945

${ }^{15}$ Article 17 paragraph 2 Constitutional Law 1945

${ }^{16}$ Adnan Buyung Nasution, Arus Pemikiran Konstitusionalieme; Tatanegara, Jakarta: Kata Hasta Pustaka, (2007), p. 204.

17 AG. Pringgodigdo, Perubahan Kabinet Presidensial Menjadi Kabinet Parlementer, Yogyakarta: Yayasan Fonds Universiteit Negeri Gadjah Mada, (tt), p. 25. 
Constitution before the amendment, the state power centered on the President is limited to a maximum of six months after the Great East Asia war.

\section{President's Prerogative Rights In The Constitution of The United Republic of Indonesia}

The Preparatory Committee for Independence established four years after the nation under The Constitution of the Republic of Indonesia on August 18th, 1945, the government of Indonesia was forced to do fundamental changes on the state's form, government system, and its primary laws. The condition that the newly-born Indonesia went through turned out to be an effect from the Dutch political government that wanted to regain their power over Indonesia after the Japanese troops surrendered to the Allies. The Netherlands tried to establish countries, such as the state of East Sumatera, the state of East Indonesia, the state of Pasundan, and the state of East Java. In line with the Dutch's effort, thus happened aggression I in the year of 1947, and aggression II in the year of $1948 .{ }^{18}$ Such condition invited worldwide concern. As a result, the United Nations urged the Dutch's and Indonesia's government to hold a negotiation, Such conditions invite world concerns. As a result, the United Nations (UN) urges the Dutch government and the Indonesian government to negotiate, which later became known as "The Round Table Convention." 19

In this conference was created three primary agreements, that is: ${ }^{20}$

a. Establish the Republic Nation of United Indonesia

b. Surrender of sovereignty to the Republic of United

c. Uni established between the Republic of United Indonesia and the Kingdom of the Netherlands.

The Constitution of the Republic of United Indonesia is a temporary constitution. Therefore, it has been provided in the constitution an institution that was given a special authority to form a permanent constitution. That institution was named "konstituante". ${ }^{21}$

The establishment of the United Republic of Indonesia on December 27th, 1949, alongside the Constitution of the Republic of United Indonesia as the fundamental law, meanwhile the form of the nation was changed from unitary to federal, and the government system from The Constitution of the

\footnotetext{
${ }^{18}$ Soehino, Hukum Tata Negara, Hubungan Funsional Antara Lembaga-lembaga Negara Tingkat Pusat Menurut Undang-Undang Dasar Republik Indonesia 1945, Yogyakarta: Liberty, Cet. 1. (1984), p. 6.

19 Taufiqurrohman Syahuri, Hukum Konstitusi: Proses dan Prosedur Perubahan UUD di Indonesia 1945-2002, Bogor: Ghalia Indonesia, Bogor, (2004), p. 120-121.

${ }^{20}$ Mohd. Kusnardi dan Harmaily Ibrahim, Pengantar. Op.Cit., p. 93.

${ }^{21}$ Taufiqurrohman Syahuri. Op.Cit., p. 124.
} 
Republic of Indonesia 1945 presidential version into parliamentary. ${ }^{22}$ Thus, the position of President is only as Head of State ${ }^{23}$ The President's position cannot be contested. ${ }^{24}$

The following are some parts of the article that regulate the President's power in the Law of the Republic of Indonesia United States, among others, the President determines who from those Ministers is required to lead their respective departments.

Furthermore, it is also explained that the appointment or termination of the time of the Ministers were carried out by a Presidential Decree. ${ }^{25}$

In Judicial sector, President at this time have power for the first time and during Federal Law has not set anyone, Leader, Vice leader, and members of Supreme Court are appointed by President after hearing the Senate. ${ }^{26}$ They might be terminated by President based on their request. ${ }^{27}$ This one too applies in the case of appointment of the Financial Supervisory Board. ${ }^{28}$ For signs of honor is set in Article 126 Law of the Republic of Indonesia Union. ${ }^{29}$

In the case of foreign relations, the Government through the President holds foreign transformation arrangements. ${ }^{30}$ Which states that President holds and ratify every agreement and another agreement with another country. Including in and deciding agreements and other agreements only made by the Presidents with the Power of Federal Law. ${ }^{31}$ To maintain foreign relations, the President appoints representatives of the Republic of Indonesia United to other countries and accepts representatives of other countries in the Republic of Indonesia. ${ }^{32}$

For this affair of defense and protection still, hold by Presidents which states on Law of the Republic of Indonesia United States state President is Supreme Commander Soldiers Republic of Indonesia United States. ${ }^{33}$ Officers are appointed, promoted and dismissed by or on behalf of the President, according to rules stipulated in the federal law. ${ }^{34}$

\footnotetext{
22 Ibid. p. 125.

${ }^{23}$ Article 69 paragraph 1 Constitution of the Republic of Indonesia Union

${ }^{24}$ Article 118 paragraph 1 Constitution of the Republic of Indonesia Union

25 Article 74 paragraph 5 Constitution of the Republic of Indonesia Union

${ }^{26}$ Article 114 paragraph 1 Constitution of the Republic of Indonesia Union

27 Article 114 paragraph 4 Constitution of the Republic of Indonesia Union

${ }^{28}$ Article 116 paragraph 1 Constitution of the Republic of Indonesia Union

${ }^{29}$ Article 126 Constitution of the Republic of Indonesia Union

${ }^{30}$ Article 174 Constitution of the Republic of Indonesia Union

${ }^{31}$ Article 175 paragraph 1 and 2 Constitution of the Republic of Indonesia Union

${ }^{32}$ Article 178 Constitution of the Republic of Indonesia Union

33 Article 182 paragraph 1 Constitution of the Republic of Indonesia Union

${ }^{34}$ Article 182 paragraph 3 Constitution of the Republic of Indonesia Union
} 


\section{President's Prerogative Rights in the Provisional Constitution of 1950}

The age of the federal state of the Republic of Indonesia under the Constitution of the Republic of Indonesia of the United States was not able to last long. The Indonesian people again chose the form of a unitary state under a new constitution, which was given the name "Provisional Constitution of the Republic of Indonesia." ${ }^{35}$ Meanwhile, the process to the changing of the Republic of Indonesia United States Constitution was done formally. The Federal Law Number 7 Years $1950,{ }^{36}$ the amendment to the Constitution of the Republic of Indonesia of the Republic of Indonesia became the Provisional Constitution of the Republic of Indonesia, based on article 127a, article 190, and article 191 paragraph (2) of the Constitution of the Republic of Indonesia. ${ }^{37}$

The changes of Constitution of Republic of Indonesia United States to Provisional Constitution 1950 it includes changes in the supremacy and form of the state, namely from the form of a federal state to the form of the United States of the Republic of Indonesia. Indeed, there has been a change in the form of the state and the government system, but the territory of the Republic of Indonesia is still intact. ${ }^{38}$

The release of the Federal Law Number 7 was commenced through the signing of the Charter of Agreement by the Government of the Republic of Indonesia and the Government of the Republic of Indonesia on May 19, 1950, to jointly implement a unitary state as the incarnation of the Republic of Indonesia based on the August 171945 Proclamation, for which a Basic Law will be treated. While. ${ }^{39}$ On August 15, 1950, President Soekarno issued a "Charter of Declaration," which stated certainty that on August 17, 1950, Unitaris's composition had returned to cover the entire territory of Indonesia. ${ }^{40}$

This is several things that set about President power on Provisional Law 1950, President has been given the power to make Ministries. ${ }^{41}$ The President appoints one of them to become Prime Minister and appoints other

\footnotetext{
35 Anhar Gonggong, Menengok Sejarah Konstitusi Indonesia, Jakarta: Ombak \& Media Presindo, (2002), pp. 23-24.

36 Taufiqurrohman Syahuri. Op.Cit., p. 126.

${ }^{37}$ Article 127a Provisional Law 1950

38 Taufiqurrohman Syahuri. Op.Cit., p. 126.

${ }^{39}$ Joeniarto, Sejarah Ketatanegaraan Republik Indonesia, Jakarta: Bina Aksara, (1984), p. 7071.

40 Muhammad Yamin, Pembahasan Undang-Undang Dasar Republik Indonesia, Jakarta: Yayasan Prapanca, (1960), pp. 37-38.

${ }^{41}$ Article 50 Provisional Law1950
} 
ministers. ${ }^{42}$ The appointment and dismissal between the Ministers and Ministers as well as the termination of the cabinet are carried out by the President's decision. ${ }^{43}$ The greater power found in this era is where the President has the right to dissolve the Regional Representative Council. ${ }^{44}$

The President also provides honors that are held by law. ${ }^{45}$ In the judicial sector too, the President has the right to give the garage the penalties imposed by a court decision. ${ }^{46}$ It was done after asking for advice from the Supreme Court just by law, and no other court was appointed to give advice. Whereas amnesty and abolition can only be given by law or by the power of the law, by the President after asking for advice from the Supreme Court. ${ }^{47}$ In the case of foreign relations, the President holds and approves agreements (treaties) and agreements with other countries. ${ }^{48}$

\section{President Prerogative Rights on Constitutional Law 1945 Years 1960 until 1998}

About prerogative rights in the 1945 Constitution, the material is the same as the 1945 Constitution which was effective at the beginning of independence.

\section{President Prerogative Rights on Constitutional Law 1945 after amendments}

The amendment to the constitution was carried out as an effort to limit the power of the President on the pretext of applying the principle of strict separation of powers between the legislature and the executive. The legislative function is associated with parliamentary functions while the President has only executive functions. This idea is what will influence the minds of the members of the People's Consultative Assembly so that the amendments to the 1945 Constitution want to reinforce the power of the People's Legislative Assembly in the Legislative field. According to Abraham Amos, changes to the Constitution occur because of an external force element that wants a change in the constitutional paradigm. ${ }^{49}$ Likewise, Satya Arinanto stated that the constitution passed at a time might lose its relevance at other times, and such a period has arrived for Indonesia, and the Constitution passed in 1945. This Constitution, which was originally

\footnotetext{
42 Article 51 Paragraph (2) Provisional Law 1950

${ }_{43}^{43}$ Article 51 Paragraph (5) Provisional Law 1950

${ }^{44}$ Article 84 Paragraph Provisional Law 1950

45 Article 87 Provisional Law 1950

${ }^{46}$ Article 107 paragraph (1) Provisional Law 1950

${ }^{47}$ Article 107 paragraph (3) Provisional Law 1950

${ }^{48}$ Article 120 paragraph (1) Provisional Law 1950

${ }^{49}$ Abraham Amos, Sistem Ketatanegaraan Indonesia (dari Orla, Orba sampai Reformasi), Jakarta: Rajawali Press, (2005), p. 286.
} 
designed as a temporary document, has been regarded as a reference point for the authoritarian rulers who have curbed the country for more than three decades. ${ }^{50}$

The President, according to the 1945 Constitution after the amendment, has several constitutional authorities to be exercised which must first be approved by the House of Representatives and the Supreme Court, including; First, declaring war, making peace, and agreements with other countries with the approval of the House of Representatives. ${ }^{51}$ Second, make international agreements that cause widespread and fundamental consequences for people's lives related to the financial burden of the state, and require changes or formation of laws with the approval of the House of Representatives. ${ }^{52}$ Third, Appoint ambassadors and consuls by taking into account the considerations of the House of Representatives.$^{53}$ In the case of the President's authority to appoint ambassadors and consuls, as well as accepting ambassadors from other countries, they are also subject to restrictions. The authority of the president in this matter is only a single one, meaning that the president does not need to seek approval from another party, now for the implementation of the President ("must") pay attention to the considerations of the House of Representatives. So, it is no longer a Prerogative of the President. It appears that the aspect of the balance of power regarding the relationship between the President and the House of Representatives appears in this issue. ${ }^{54}$ Fourth, Receive placement of ambassadors of other countries by observing the considerations of the House of Representatives. ${ }^{55}$ Fifth, Giving clemency and rehabilitation by paying attention to the consideration of the Supreme Court. ${ }^{56}$ Sixth, Giving amnesty and abolition by paying attention to the considerations of the House of Representatives. ${ }^{57}$

The authority of the President to grant clemency, amnesty, abolition, and rehabilitation as stipulated in article 14 also has limitations. Now in the case of the President giving Clemency and Rehabilitation, ("must") consider the Supreme Court. If the President gives amnesty and abolition, also ("must") also pay attention to the considerations of the House of Representatives. Here, there is an aspect of the balance of power not only

\footnotetext{
50 Satya Arinanto, Hak Asasi Manusia Dalam Transisi Politik Di Indonesia, Jakarta: Pusat Studi Hukum Tata Negara Fakultas Hukum Universitas Indonesia, (2005), pp. 258-259.

${ }^{51}$ Article 11 Paragraph (1) of the 1945 Constitution of the Republic of Indonesia

${ }_{52}$ Article 11 Paragraph (2) of the 1945 Constitution of the Republic of Indonesia

${ }^{53}$ Article 13 Paragraph (2) of the 1945 Constitution of the Republic of Indonesia

${ }^{54}$ Ni'matul Huda. Op., Cit. p. 126-127.

${ }_{55}$ Article 13 Paragraph (3) of the 1945 Constitution of the Republic of Indonesia

${ }^{56}$ Article 14 Paragraph (1) of the 1945 Constitution of the Republic of Indonesia

${ }^{57}$ Article 14 Paragraph (2) of the 1945 Constitution of the Republic of Indonesia
} 
between the President and the House of Representatives but also with the Supreme Court. ${ }^{58}$

Also there is also the authority that is owned by the President which is regulated by law, among others:

a. Giving degrees, honors, and other honors that are regulated by law. ${ }^{59}$

Likewise, the President's authority in giving titles, service marks, and other honors, as stipulated in article 15, also experienced a reduction. The President no longer has the Prerogative, because the President's authority to give titles, honors, and other honors will be regulated by law. This means that there is a measuring instrument or clear criteria in its application. Experience so far in granting titles, honors and other honors is only dependent on the subjective "loyalty" assessment of the President. This change implies that implicitly there must be approval from the House of Representatives. ${ }^{60}$

b. The President declares a state of danger. The conditions and consequences of the hazard are determined by law. ${ }^{61}$ The President, authorized to declare a state of danger. It means that if all or part of the State's territory will be declared in a state of civil emergency, military emergency, or state of war, it is entirely the authority of the President without the approval of another position. ${ }^{62}$

There is also the authority possessed by the President in the 1945 Constitution after amendments which do not need consideration from the House of Representatives and the Supreme Court and are not regulated by law, including:

a. The President holds the highest authority over the Army, Navy and Air Force ${ }^{63}$ Harun Alrasid ${ }^{64}$ explicitly did not say that the president within the framework of the 1945 Constitution has prerogative rights, but from his description, it can be seen that the President has prerogative rights. For example, the President holds the highest authority over the Army, Navy, and Air Force, so that the top level decisions in the military field are in the hands of the President.

b. To appoint and dismiss the minister of state. ${ }^{65}$ The President also without the approval of other officials, is authorized to appoint ministers. From the provisions of the minister appointed and dismissed by the

\footnotetext{
${ }^{58}$ Ni'matul Huda. Op.Cit., p. 127.

${ }^{59}$ Article 15 of the 1945 Constitution of the Republic of Indonesia

${ }^{60} \mathrm{Ni}$ 'matul Huda. Loc.Cit.

${ }^{61}$ Article 12 of the 1945 Constitution of the Republic of Indonesia

${ }^{62}$ Ni'matul Huda. Op.Cit., p. 124.

${ }^{63}$ Article 10 of the 1945 Constitution of the Republic of Indonesia

${ }^{64}$ Harun Alrasid, Jabatan Presiden RI Sebuah Tinjauan Hukum Tata Negara, Pidato Dies Rede pada Sidang Senat Terbuka Dalam Rangka Dies Natalis UII Yogyakarta, (1999), p. 15.

${ }^{65}$ Article 17 paragraph (2) of the 1945 Constitution of the Republic of Indonesia
} 
president, associated with the provision that the President holds the governmental power, the conclusion is that the Presidential Administration system applies. ${ }^{66}$ Discussion of the State Ministry regulated in Article 17 of the 1945 Constitution. It turns out that what is done against this article does not have too much impact on the President's Power, as in other articles, because it only changes the editorials of paragraphs (2) and (3) so that it reads:

c. Ministers are appointed and terminated by the President

d. Every Minister in charge of Specific Affairs in Government Generally it is understood that the 1945 Constitution before the change gave Prerogative authority to the President through articles 10 through article 15 and article 17, so that the President in exercising his authority did not need to ask for approval from other institutions, for example, the House of Representatives. However, when the 1945 Constitution was amended, the structure of the 1945 Constitution experienced extraordinary changes. The articles that had previously given full authority to the President to administer the government, after the amendment to the 1945 Constitution the President's authority experienced a considerable reduction. There is a requirement for the President to seek approval from the House of Representatives ${ }^{67}$ but there are also those who "must" pay attention to the deliberations of the House of Representatives (DPR $)^{68}$, or consideration of the Supreme Court. ${ }^{69}$

\section{Conclusion}

It's shown by constitution applied and applies today in Indonesia that the using of Prerogative Rights experiences the tides. Its affected by checks and balances concept and distribution of power. Therefore the use of prerogative rights as in the previous constitution was more directed to heavy executives who did not require confirmation from other state institutions. Now, it has begun to be restricted thus the use of the term prerogative privileges is no longer as pure as before.

\footnotetext{
${ }^{66}$ Ni'matul Huda. Op.Cit., p. 124.

${ }^{67}$ Article 11 and 15 of the 1945 Constitution of the Republic of Indonesia

${ }^{68}$ Article 13 and 14 paragraph 2 of the 1945 Constitution of the Republic of Indonesia

${ }^{69}$ Article 14 paragraph 1 of the 1945 Constitution of the Republic of Indonesia
} 


\section{A. Books}

\section{Bibliography}

AG. Pringgodigdo, t.t. Perubahan Kabinet Presidensial Menjadi Kabinet Parlementer. Yogyakarta: Yayasan Fonds Universiteit Negeri Gadjah Mada.

Amos, Abraham. (2005). Sistem Ketatanegaraan Indonesia (dari Orla, Orba sampai Reformasi). Jakarta: Rajawali Press.

Arinanto, Satya. (2005). Hak Asasi Manusia Dalam Transisi Politik Di Indonesia. Jakarta: Center of Constitutional Law Studies, Law Faculty University of Indonesia.

Ashidiqqie, Jimly. (2007). Pokok-Pokok Hukum Tata Negara Indonesia Pasca Reformasi. Jakarta: Buana Ilmu Populer.

Barnet, Hilaire. (2002). Constitutional \& Administrative Law. United Kingdom: Cavendish Publishing Limited, The Glass House.

Gonggong, Anhar. (2002). Menengok Sejarah Konstitusi Indonesia, Jakarta: Ombak \& Media Presindo.

Huda, Ni'Matul. (2003). Politik Ketatanegaraan Indonesia; Kajian Terhadap Dinamika Perubahan UUD 1945. Yogyakarta: Law Faculty Islam Indonesia University Press.

Ibrahim, Mohd. Kusnardi dan Harmaily. (1983). Pengantar Hukum Tata Negara. Jakarta: Center of Constitutional Law Studies, Law Faculty of University of Indonesia.

Joeniarto. (1984). Sejarah Ketatanegaraan Republik Indonesia. Jakarta: Bina Aksara.

MD, Moh. Mahfud. (1999). Hukum dan Pilar-Pilar Demokrasi. Yogyakarta: Gama Media.

Moh. Kusnardi dan Harmaily Ibrahim. (1983). Pengantar Hukum Tata Negara Indonesia. Jakarta: Center for Constitutional Law Studies, Law Faculty of Indonesia University.

Nasution, Adnan Buyung. (2007). Arus Pemikiran Konstitusionalieme ;Tatanegara. Jakarta: Kata Hasta Pustaka

Purnomowati, Reni Dwi. (2005). Implementasi Sistem Bikameral dalam Parlemen Indonesia. Jakarta: Rajawali Press.

Ranadireksa, Hendarmin. (2007). Visi Bernegara : Arsitektur Konstitusi Demokratik, Mengapa Ada Negara yang Gagal Melaksanakan Demokrasi. Bandung: Fokusmedia.

Soehino. (1984). Hukum Tata Negara, Hubungan Funsional Antara Lembaga-lembaga Negara Tingkat Pusat Menurut Undang-Undang Dasar Republik Indonesia 1945. Yogyakarta: Liberty.

Soerjono Soekanto and Sri. (2001). Penelitian Hukum Normatif Suatu Tinjauan Singkat. Jakartta:Raja Grafindo Persada. 
Syahuri, Taufiqurrohman. (2004). Hukum Konstitusi: Proses dan Prosedur Perubahan UUD di Indonesia 1945-2002. Bogor: Ghalia Indonesia,

Tim Prima Pena. Kamus Besar Bahasa Indonesia. Gita Media Press, tt.

Wilopo. (1976). Zaman Pemerintahan Partai-Partai dan KelemahanKelemahannya. Jakarta: Yayasan Idayu

Yamin, Muhammad. (1960). Pembahasan Undang-Undang Dasar Republik Indonesia. Jakarta: Yayasan Prapanca.

\section{B. Journal and Article}

Harun Alrasid, Jabatan Presiden RI Sebuah Tinjauan Hukum Tata Negara, Pidato Dies Rede pada Sidang Senat Terbuka Dalam Rangka Dies Natalis UII Yogyakarta, 8 November 1999.

Manan, Bagir. (2000). "UUD 1945 Tak Mengenal Hak Prerogatif", Republika, Sabtu, 27 May 2000.

Riri Nazriah. "Pemberhentian Jaksa Agung dan Hak Prerogatif Presiden", Constitute Journal, 7 (5), (2010).

\section{Legislation}

Basic Law of the Republic of Indonesia.

Constitution of the Republic of Indonesia.

Provisional Constitution 1950.

The Constitution of the Republic of Indonesia 1945 